\title{
Повышение эффективности ОБСЕ: практические рекомендации бывшего Генерального секретаря
}

\author{
Томас Гремингер*
}

\section{Аннотация}

В статье предлагаются рекомендации по повышению эффективности ОБСЕ, сформулированные по итогам реализации программы реформ «Соответствие поставленным задачам», которой автор руководил в период своего пребывания в должности Генерального секретаря ОБСЕ (2017-2020 гг.). ОБСЕ обладает потенциалом для реформирования, но очевидно, что этот процесс нуждается в большей политической поддержке. Автор рекомендует предоставить секретариату ОБСЕ полномочия по внесению изменений в рабочие и управленческие процессы в организации. Рекомендации касаются также рационализации бюджетного процесса, своевременного принятия бюджета исполнительных структур и выделения им достаточных ресурсов, укрепления потенциала секретариата в области стратегического планирования, поощрения координации между исполнительными структурами и совершенствования методов осуществления ими программной деятельности.

\section{Ключевые слова}

Соответствие поставленным задачам, управление, бюджетный процесс, стратегическое планирование, программная деятельность

Для цитирования этой публикации: Гремингер Т. Повышение эффективности ОБСЕ: практические рекомендации бывшего Генерального секретаря // ОБСЕ Insights 1/2021 - БаденБаден: Номос, 2022. - URL: https://doi.org/10.5771/9783748911463-01

\section{Введение ${ }^{1}$}

ОБСЕ осуществляет свою деятельность в сложной политической обстановке. Падает доверие к многосторонним институтам и механизмам решения глобальных проблем. В политике превалируют односторонние подходы, заключение сделок. В политике ключевых государств евро-атлантического и евразийского пространства безопасности усиливается поляризация. В регионе ОБСЕ снова стали реальностью вооруженные конфликты. Разваливаются режимы контроля над вооружениями. Воз-

* Томас Гремингер, Федеральный департамент иностранных дел Швейцарии, thomas.greminger@eda.admin.ch. 
растает риск военных инцидентов. И в то же самое время мы сталкиваемся с широким спектром транснациональных угроз, эффективно противостоять которым можно только на основе трансграничного сотрудничества. К таким угрозам относятся терроризм и воинствующий экстремизм, киберугрозы со стороны государств и негосударственных субъектов, торговля людьми, незаконный оборот оружия, культурных ценностей и наркотиков, а также проблемы, связанные с нелегальной миграцией. В последнее время особого внимания требуют влияющие на безопасность климатические и технологические изменения (в частности, связанные с развитием искусственного интеллекта). В результате сложилась парадоксальная ситуация: многостороннее сотрудничество ставится под вопрос, пространство для диалога сужается в то время как потребность в сотрудничестве и подлинном диалоге велика как никогда. Эта тенденция проявляется и в ОБСЕ.

Если для реагирования на современные угрозы безопасности необходимо многостороннее сотрудничество, то как мы можем укрепить ОБСЕ в качестве форума для инклюзивного диалога, посредника, содействующего эффективному сотрудничеству в области безопасности? С какими препятствиями сталкивается организация и как их преодолеть? Данные вопросы в первую очередь занимали автора этих строк, когда он вступал в должность Генерального секретаря ОБСЕ в 2017 году. Во взаимодействии с директорами департаментов и подразделений секретариата и под руководством созданной группы обеспечения стратегической политики была разработана программа «Соответствие поставленным задачам», представленная мною государствам-участникам в феврале 2018 года². За прошедшие три года были достигнуты неоднозначные результаты. Анализируя реализацию программы «Соответствие поставленным задачам», можно констатировать целый ряд изменений, способствовавших повышению эффективности ОБСЕ. Положительный вывод на будущее состоит в том, что реформы возможны. Но в то же время важнейшие реформы были сорваны на раннем этапе или еще не доведены до конца. Совершенно очевидно, что, для того чтобы обеспечить способность ОБСЕ и далее эффективно реагировать на вызовы в области безопасности и использовать свои ограниченные ресурсы, необходимо продолжать реформаторские усилия.

В статье вниманию читателей ОБСЕ Insights предлагаются четыре темы, которых касалась программа «Соответствие поставленным задачам»3.

- пересмотр рабочих процессов в секретариате;

- обеспечение ОБСЕ достаточными ресурсами;

- продвижение ОБСЕ как форума для инклюзивного диалога;

- укрепление сотрудничества в рамках программной деятельности.

Ниже дается краткая оценка того, что достигнуто на сегодняшний день и что стало причиной неудач в тех случаях, когда достичь поставленные цели не удалось. В заключении изложены рекомендации государствам-участникам и секретариату. 


\section{Достижения и неудачи программы «Соответствие поставленным задачам»}

\section{Пересмотр управленческих процессов}

С момента своего создания более двух десятилетий назад секретариат ОБСЕ развивался под влиянием менявшейся обстановки. Его рабочие процессы адаптировались по мере появления новых вызовов, возрастания рабочей нагрузки, изменения приоритетов государств-участников и постоянного сокращения бюджета. Условия работы менялись также под влиянием новых технологий и управленческих методов. Все это порождало необходимость систематического проведения обзора централизованных управленческих процессов в секретариате в целях повышения эффективности его работы. С этой целью такой обзор был начат в апреле 2018 года. В нем при поддержке международной консалтинговой фирмы принял участие весь персонал секретариата. В общей сложности были разработаны 80 мер по оптимизации деятельности секретариата. По состоянию на июль 2020 года 68 из них были реализованы, 5 отменены и 7 продолжали внедряться в рамках самостоятельных процессов. Были осуществлены, в частности, следующие изменения:

- благодаря совершенствованию инструментов контроля и отчетности повышена прозрачность расходов;

- в целях сокращения рабочей нагрузки и административных расходов внедрен новый инструментарий управления командировками;

- создана электронная платформа для регистрации и подготовлены инструкции по организации и проведению конференций и совещаний;

- снижена административная нагрузка в сфере закупок;

- создана новая электронная платформа для набора персонала;

- внедрен вводный онлайн-инструктаж для новых сотрудников и всего персонала ОБСЕ;

- установлен новый порядок утверждения внебюджетных проектов, позволяющий дифференцировать проекты в зависимости от уровня риска и ускорить процесс их рассмотрения.

Были оптимизированы процессы в таких сферах как логистика, эксплуатация зданий, внутренняя координация, коммуникации, цифровизация управления и расчетов с персоналом. Многие из этих изменений обнаружили общую закономерность: при внедрении цифровых технологий в целях повышения качества обслуживания происходило одновременное сокращение затрат. И хотя пересмотр управленческих процессов изначально был направлен не на сокращение затрат, а на перераспределение ресурсов с целью увеличить отдачу от осуществляемой деятельности, в одном только 2019 году это позволило сэкономить около 300 тыс. евро. К инициативам, готовым к реализации, относятся создание общих сервисных центров, занимающих- 
ся такими вопросами как поддержка в сфере информационно-коммуникационных технологий (ИКТ), управление персоналом, а также привлечение внебюджетных средств государств и неправительственных организаций, неденежных пожертвований.

Хотя обзор деятельности секретариата был сосредоточен в первую очередь на внутренних процессах, внимание было уделено и его организационной структуре. Быстрые результаты дали объединение отдела по работе с документацией с Центром документации ОБСЕ в Праге, а также функций, связанных с ИКТ, в рамках специализированного подразделения департамента управления и финансов. Однако других изменений, например, переподчинения координатора по вопросам этики и программы по гендерным вопросам напрямую Генеральному секретарю, добиться не удалось из-за сопротивления государств-участников. Такие структурные изменения отражаются в штатном расписании, которое является частью сводного бюджета, поэтому они требуют утверждения на основе консенсуса. С той же проблемой столкнулась наша попытка учредить должность второго заместителя руководителя секретариата. Поскольку ОБСЕ не желает финансировать полную штатную единицу заместителя Генерального секретаря, эти обязанности официально возлагаются на и без того загруженного директора Центра по предотвращению конфликтов. Поэтому я назначил своим вторым заместителем директора канцелярии Генерального секретаря. Функции двух заместителей были четко разграничены: директор Центра по предотвращению конфликтов взял на себя обязанности заместителя по внешним вопросам, связанным с конфликтным циклом, а руководитель офиса Генерального секретаря отвечал за внутренние вопросы, связанные с управлением. Это великолепно работало на практике, и государства-участники никогда не ставили такую организацию работы под сомнение. Но когда мы попытались официально закрепить такое распределение функций путем внесения изменений в штатное расписание, руководитель одной из делегаций развернул успешную кампанию против данного решения, обосновывая его неприемлемость тем, что оно не было должным образом обсуждено с государствами-участниками.

О пересмотре управленческих процессов в секретариате мы подробно информировали делегации и регулярно предоставляли им информацию в рамках «часа Генерального секретаря» в Постоянном совете и в ходе встреч с послами в узком составе. Первоначально эта информация была встречена государствами-участниками с одобрением и даже энтузиазмом, но со временем их интерес к управленческим вопросам угас. В ходе обсуждений бюджета в консультативном комитете по управлению и финансам полученное в результате перемен повышение эффективности не вызвало большого воодушевления. При этом несколько государств заблокировали внесение хорошо обоснованных изменений в организацию бюджетного процесса, ограничив возможности Генерального секретаря в решении даже управленческих вопросов. Государствам-участникам следовало бы предоставить секретариату определенную свободу действий и отказаться от микро-менеджмента. Им следует сосре- 
доточиться на политических механизмах достижения консенсуса и осуществления совместных действий, исходя из общих обязательств.

Склонность государств-участников скрупулезно контролировать деятельность секретариата резко контрастирует с утверждением о том, что ответственность и обязанности в сфере управления составляют не подлежащую сомнениям основу полномочий Генерального секретаря. Как это ни парадоксально, именно те государства, которые настаивают на том, что Генеральный секретарь является «всего лишь» главным административным должностным лицом, не позволяют ему беспрепятственно выполнять эту функцию. На основе личных наблюдений у автора сложилось мнение, что явное большинство государств-участников ОБСЕ хотело бы видеть активного, известного в дипломатических кругах Генерального секретаря, и его мандат предоставляет ему такие возможности. Но на практике есть два вопроca, в отношении которых существует довольно широкий простор для различных интерпретаций. Один касается политической и дипломатической роли Генерального секретаря, а другой - его координирующей роли как главного административного должностного лица. В соответствующих решениях Совета министров представлено общее описание политических функций Генерального секретаря ${ }^{4}$, а конкретные политические рамки, в пределах которых занимающее эту должность лицо осуществляет свою деятельность, в конечном счете определяет действующий Председатель. За время пребывания в должности Генерального секретаря автор столкнулся с тем, что у каждого Председателя свои представления о роли Генерального секретаря, к которым ему приходится приспосабливаться. Координирующая роль Генерального секретаря касается как взаимодействия исполнительных структур в ходе реализации конкретных программ, так и регулирования кризисов, - это мы наблюдали в связи с пандемией COVID-19. Эффективная координация со стороны секретариата необходима для того, чтобы две главные задачи - проявлять должную заботу о сотрудниках и обеспечивать бесперебойность в выполнении возложенных на секретариат задач - стабильно выполнялись в рамках всей организации. По мере возрастания потребности в междисциплинарных мерах реагирования на сложные угрозы безопасности возрастает и необходимость в повышении уровня координации программной деятельности ОБСЕ.

\section{Обеспечение достаточными ресурсами}

В своих программных заявлениях государства-участники неизменно подчеркивают востребованность ОБСЕ как форума для диалога, посредника в регулировании кризисов и урегулировании конфликтов, а также как организации, содействующей реагированию на угрозы для безопасности и выполнению государствами принятых ими в рамках ОБСЕ обязательств. Но это не ведет автоматически к выделению адекватных ресурсов, необходимых организации для решения стоящих перед ней 
задач. В данной связи встает целый ряд вопросов. Мы остановимся на бюджетном процессе, размере сводного бюджета, сроках его принятия и на шкалах взносов. Мы не рассматриваем в данной статье вопросы, касающиеся внебюджетных ресурсов, несмотря на их особую актуальность с точки зрения возможностей значительного расширения ресурсной базы ОБСЕ. Обсуждение стратегии мобилизации ресурсов потребовало бы рассмотрения порядка и правил для более стратегического использования текущих внебюджетных средств и привлечения новых источников финансирования, таких как агентства по оказанию помощи, международные финансовые учреждения и частный сектор.

В принципе у государств-участников не вызывает сомнений необходимость изменения бюджетного процесса. В настоящее время он является сложным, трудоемким и длительным. Это позволяет государствам вмешиваться в мельчайшие детали финансовой деятельности секретариата и других исполнительных структур и увязывать (часто узкие) политические и личные цели с более общими вопросами оперативной деятельности. Введение более длительного бюджетного цикла позволило бы реализовать более стратегический подход к планированию и обеспечить большее соответствие между ресурсами, с одной стороны, и политической и предусмотренной мандатом деятельностью - с другой. В 2018 году секретариат подготовил и представил на рассмотрение государств-участников предложение по реформированию бюджетного процесса. В нем содержались две основные идеи: расширить горизонт планирования программной деятельности с одного года до четырех и утверждать бюджет на два года. При этом имелось в виду, что конкретное распределение финансовых ресурсов по-прежнему будет утверждаться государствами на ежегодной основе. Предложение было встречено хорошо. Даже делегация страны, являющейся одним из основных плательщиков взносов в бюджет, не выразила принципиального несогласия (благодаря интенсивной подготовительной работе, включая переговоры в столице этого государства), но выдвинула в качестве условия два важных требования: реформа должна быть представлена в виде пилотного проекта, а планирование программной деятельности предлагалось ограничить двумя годами (недостаток доверия к институтам не позволял согласиться на составление четырехлетнего плана).

Когда незадолго до летнего перерыва 2018 года итальянское Председательство собиралось представить соответствующее предложение на утверждение Постоянного совета, возникло новое препятствие, из-за которого принятие этого и других предложенных секретариатом решений в конечном итоге было отложено почти на девять месяцев. Речь шла о вопросе, совершенно не связанном с бюджетной реформой, - о так называемой защитительной оговорке. Поскольку это - типичная для внутренней кухни ОБСЕ ситуация, остановимся на ней немного подробнее.

В июне 2018 года к документам, разосланным государствам-участникам через официальную систему распространения документации, была добавлена оговорка, поясняющая, что секретариат не несет ответственности за их содержание. Это 
вызвало гневную реакцию со стороны одного государства-участника, которое восприняло разосланные материалы как направленный против него шаг другого государства. Несколько государств-участников до этого действительно регулярно жаловались Председательству и секретариату на неправомерное использование системы рассылки документации для распространения информации, исходящей от официально не признанных квази-государственных образований. Хотя такая оговорка включалась во все без исключения документы на основании решения Постоянного совета, упомянутое государство-участник упорно продолжало трактовать это как недружественный акт. Несмотря на интенсивные переговоры на всех уровнях - от посла до министра иностранных дел, убедить данное государство снять свои возражения не удалось. Вопрос был решен лишь в первом квартале 2019 года благодаря вмешательству действующего Председателя, министра иностранных дел Словакии Мирослава Лайчака. Это позволило разблокировать другие важные процессы, но возродить динамику бюджетной реформы было уже невозможно. Упрощенная бюджетная документация и более удобный в использовании отчет об ориентированной на результат программной деятельности - вот все, что осталось от первой попытки осуществления бюджетной реформы.

Вторую попытку планировалось предпринять в 2020 году, но на этот раз «окно возможностей» открылось слишком поздно, поскольку бюджет ОБСЕ был утвержден только в мае. Кроме того, из-за вызванного коронавирусом кризиса проводить обмен мнениями с государствами-участниками стало сложнее. Несмотря на эти трудности, переговоры по двухлетнему бюджету и долгосрочному планированию деятельности были возобновлены. Обсуждение возможности рассчитанного на более длительную перспективу планирования капиталовложений, казалось, набирало обороты, но разразившийся в июле 2020 года кризис руководства ОБСЕ опять отложил рассмотрение реформы.

На протяжении уже многих лет предпринимаются попытки пересмотреть шкалы взносов, на основе которых определяется ежегодный вклад каждого из 57 государств-участников ОБСЕ в бюджет организации. Формула, по которой рассчитываются взносы государств, является сложной и устаревшей. Неоднократные попытки модернизировать шкалы взносов и привести их в соответствие с современным распределением экономического потенциала государств до сих пор не увенчались успехом. Поскольку одно государство-участник особенно настойчиво увязывает свое согласие на утверждение бюджета с пересмотром формулы расчета взносов, Председательствам ОБСЕ приходится заниматься решением этой трудной задачи. Речь идет о сравнительно небольших суммах, но дискуссии становятся политизированными и уходят далеко в сторону от практической целесообразности. Стоящая перед председательствами задача невыполнима, пока основные заинтересованные стороны не готовы к корректировке величины своих взносов. В таких условиях, конечно, несправедливо ставить утверждение сводного бюджета в зависимость от пересмотра шкал взносов. Это не означает, что их не нужно пересматривать. Как 
раз наоборот. Однако данная проблема не может быть решена на чисто техническом уровне, как показали усилия, предпринятые Словакией в период ее председательства в ОБСЕ в 2019 году. Чтобы найти решение, стране-председателю потребуется задействовать значительный политический капитал, а основным заинтересованным сторонам - проявить готовность двигаться вперед. В то же время важную роль играют технические детали, зачастую весьма мелкие, которые ускользают от понимания высокопоставленных дипломатов и официальных лиц в столицах, занимающихся такими вопросами лишь от случая к случаю. Возможно, к решению данного вопроса стоит привлечь бывшего министра финансов.

В 2020 году, невзирая на возникшие в связи с пандемией сложности для функционирования ОБСЕ, государства-участники продолжили многоречиво и придирчиво обсуждать сводный бюджет 2020 года, который должен был быть принят до конца 2019 года. При всем умелом руководстве со стороны Председательства он был утвержден только в конце мая, то есть с пятимесячным опозданием. К сожалению, в ОБСЕ позднее утверждение бюджета - уже не исключение, а правило. Данный процесс ложится тяжелым бременем на каждое Председательство и отвлекает время, энергию и внимание государств-участников от решения более существенных вопросов. Из-за этого остается меньше времени на обсуждение вопросов, касающихся реформ и значительно осложняется обеспечение бесперебойной работы организации. Пока сводный бюджет не утвержден, финансирование деятельности осуществляется поквартально (а затем помесячно) исходя из бюджета предыдущего года. Что еще хуже, это не позволяет начать осуществление новой программной деятельности. Своевременное принятие бюджета имеет поэтому огромное значение для эффективного функционирования ОБСЕ, и государства-участники должны рассматривать это как задачу стратегического порядка. Регулярных отчаянных призывов действующего Председателя для этого мало, необходимо создать механизм, обязывающий государства-участники своевременно принимать сводный бюджет.

Затянувшееся обсуждение сводного бюджета 2020 года не привело к увеличению финансирования. В результате девятый год подряд наблюдался «нулевой рост» номинального бюджета. Таким образом, ОБСЕ снова потеряла около двух процентов своей реальной покупательной способности. Безусловно, любая организация может какое-то время продолжать свою деятельность в условиях жесткой экономии, но есть предел тому, как долго можно делать больше, тратя меньше. Этот предел явно был достигнут исполнительными структурами ОБСЕ после многих лет нулевого номинального роста бюджета при увеличении объема решаемых ею задач (например, по обеспечению деятельности Специальной мониторинговой миссии в Украине (CMM)).

Некоторые государства отвечают, что объем средств, которые они выделяют на деятельность ОБСЕ, начиная с 2014 года вырос, поскольку СММ имеет самостоятельный бюджет, почти равный сводному бюджету организации. Это верно. Но при этом упускается из вида то, что с развертыванием СММ значительно увеличилась 
рабочая нагрузка на секретариат, а его бюджет остался прежним. Не допустить серьезных сбоев в выполнении мандатов секретариата удалось за счет повышения эффективности, достигнутого в результате внедрения новых управленческих процессов, и более частой практики решения определенных задач силами других исполнительных структур. Однако пришло время, когда государствам-участникам следует либо существенно сократить объем возлагаемых на секретариат задач, либо отказаться от принципа нулевого номинального роста бюджета.

Практика показывает, что блокирующие утверждение сводного бюджета государства-участники в других случаях поступают совершенно иначе. Так, Бюджет СММ 2020 года был принят своевременно, несмотря на его увеличение на восемь с половиной процентов. Столицы были заинтересованы в обеспечении СММ необходимыми ресурсами, и как только возник риск возможной задержки утверждения бюджета от них стали поступать однозначные политические сигналы. Чем объяснить такой контраст? Мы полагаем, что у государств-участников не вызывает возражений четко очерченная роль (и необходимость) СММ. Если бы сводный бюджет ОБСЕ основывался на более четких приоритетах, согласованных государствами-участниками, например, на уровне министров иностранных дел, его утверждение проходило бы намного проще. В нынешней ситуации обструкция обходится недорого отдельным государствам, но наносит ущерб организации в целом.

\section{Продвижение ОБСЕ как форума для инклюзивного диалога}

Одна из сильных сторон ОБСЕ со времени проведения в 1975 году Совещания по безопасности и сотрудничеству в Европе (СБСЕ) заключается в том, что она является открытым форумом для поддержания диалога. В период «холодной войны» и в 1990-е годы СБСЕ (переименованное в ОБСЕ в 1995 году) было площадкой, на которой государства обсуждали и разрешали широкий спектр разногласий. В бытность председателем Постоянного совета в 2014 году во время председательства Швейцарии в ОБСЕ и Генеральным секретарем организации автор был свидетелем угасания культуры диалога и сотрудничества. Заседания органов ОБСЕ использовались для зачитывания речей, набирания очков и упражнения в публичной дипломатии. Вместе с председательствами ОБСЕ мы стремились возродить и укрепить уникальную роль организации как площадки, на которой могут собраться представители придерживающихся различных взглядов пятидесяти семи стран, чтобы в ходе конструктивного диалога наладить сотрудничество на основе общего стремления к безопасности. Работа по возрождению диалога в ОБСЕ в рамках программы «Соответствие поставленным задачам» велась по трем направлениям: создание в секретариате потенциала для стратегического планирования, предоставление дополнительных возможностей для неформального диалога и поддержка «структурированного диалога» - неофициальной рабочей группы государств-участников, учрежденной 
решением гамбургской встречи Совета министров 2016 года с целью обсуждения текущих и перспективных вызовов и угроз для безопасности.

В период председательства Швейцарии в ОБСЕ мы констатировали, что секретариату не хватает потенциала для среднесрочного и долгосрочного планирования, поскольку его подразделения, занимающиеся вопросами политики и координацией деятельности, были полностью поглощены повседневной деятельностью. Для восполнения этого дефицита в конце 2017 года была создана группа обеспечения стратегической политики, финансируемая из внебюджетных средств. В ее состав вошли эксперты, командированные Соединенными Штатами Америки, Российской Федерацией, Европейским союзом и Швейцарией. Группа была призвана обеспечить бо́льшую преемственность процессов планирования деятельности ОБСЕ и предоставлять Председательству и «тройке» (действующему, предыдущему и следующему председателям) рекомендации по стратегическим вопросам политики. Группа оказала содействие председательствам 2019 и 2020 годов - Словакии и Албании - в определении приоритетов, а Центру по предотвращению конфликтов - в разработке региональной стратегической концепции для Западных Балкан и Центральной Азии. Она подготовила рекомендации для будущих председательств ОБСЕ и проработала возможные последствия для ОБСЕ различных сценариев развития отношений с Китаем. Группа также способствовала приданию более стратегического характера планированию программной деятельности, в рамках которого выделение бюджетных ресурсов стало увязываться с политическими приоритетами.

Не меньшее значение, чем стратегический подход к выделению средств из бюджета, имеет более широкий подход к планированию деятельности ОБСЕ, финансируемой за счет внебюджетных средств. Ее масштабы возрастают, и она приобретает особую значимость, когда речь идет об инновациях и новых направлениях деятельности организации. В этой связи была учреждена должность координатора деятельности по стратегическому планированию и мобилизации ресурсов.

Стратегическое планирование в ОБСЕ зависит, с одной стороны, от возможностей секретариата осуществлять планирование, а с другой - от политической и практической поддержки со стороны Председательства, «тройки» и государствучастников. Первостепенное значение, несмотря на всю сложность, имеет согласование политических приоритетов, определяемых Председателем и «тройкой». Как правило, подход каждого Председательства к ОБСЕ ограничивается рамками его двенадцатимесячного мандата. Однако было бы разумно расширить горизонт планирования, в идеале - до трех или четырех лет. В 2008 году, когда в ОБСЕ председательствовала Финляндия, была проведена встреча пяти следовавших друг за другом председательств. Швейцария и Сербия совместно согласовали планы работы своих председательств на 2014 и 2015 годы. К сожалению, эта модель не прижилась. На данный момент имеются необходимые условия для долгосрочного планирования, так как последовательность председателей ОБСЕ определена до конца 2023 года (Швеция, Польша, Северная Македония). 
Официальные диалоговые форумы ОБСЕ, такие как Постоянный совет и Форум по сотрудничеству в области безопасности, во многом превратились в площадки для публичной дипломатии в ее жесткой, конфронтационной форме. Инициированная в рамках программы «Соответствие поставленным задачам» серия встреч под общим названием «Темы для обсуждения» предоставила возможности для неформального диалога. Для обсуждения последних исследований и публикаций с представителями государств-участников и сотрудниками ОБСЕ в штаб-квартиру секретариата приглашались эксперты. Помимо прочего это был хороший повод пригласить в секретариат членов делегаций. Еще одной незаменимой неформальной площадкой для диалога являются «Дни безопасности», инициированные моим предшественником в должности Генерального секретаря Ламберто Заньером. С созданием в секретариате группы обеспечения стратегической политики у нас появился потенциал, необходимый для целенаправленной разработки концепции этих мероприятий и организации согласованной последующей деятельности. Недавние «Дни безопасности» были посвящены таким вопросам, как будущее полевых присутствий ОБСЕ, предотвращение военных инцидентов, цели устойчивого развития, технологические изменения и уроки парижской Хартии.

Помимо этого мы поощряли создание аналитическими центрами неформальных площадок для диалога по актуальным вопросам. В ответ на наш призыв и при политической поддержке действующего Председателя Мирослава Лайчака консорциум, сформированный Фондом им. Фридриха Эберта и братиславским форумом GLOBSEC, начал реализацию Инициативы в области безопасности, основанной на сотрудничестве. Данная инициатива направлена на продвижение концепции безопасности, основанной на сотрудничестве, в кругах, участвующих в формировании политики европейской безопасности, и на разработку новых идей в целях укрепления многостороннего сотрудничества и сотрудничества в области безопасности в Европе.

«Структурированный диалог» в рамках ОБСЕ, изначально предназначенный для стимулирования дискуссии о контроле над вооружениями ${ }^{5}$, на практике способствовал началу конструктивного обмена мнениями о современном восприятии угроз, военных доктринах и мерах по снижению напряженности. Государства-участники проявили также интерес к использованию этого форума для разработки мер по повышению транспарентности в военной области, таких как типовой брифинг о крупных военных учениях или руководство по передовой практике в области предотвращения и урегулирования военных инцидентов.

Мы прилагали все усилия для поддержания «структурированного диалога», особенно в рамках взаимодействия с правительствами и такими организациями, как НАТО, несмотря на то, что некоторые, в особенности - скептически настроенные в отношении «структурированного диалога» государства-участники неустанно подчеркивали, что только они являются участниками данного диалога и только они принимают соответствующие решения. Такие заявления продиктованы боязнью 
утратить контроль над процессом в том случае, если инициатива в его продвижении перейдет к многочисленной группе государств, которые поддерживают этот диалог, секретариату, который полон решимости способствовать его успеху, а также заинтересованным исследовательским центрам и организациям гражданского общества. «Структурированный диалог» сталкивается с проблемами и в связи тем, что его основные участники придерживаются взаимоисключающих представлений о его приоритетах. Сохранить динамизм данного процесса непросто также потому, что каждый год неофициальную рабочую группу возглавляет новое государство-участник. Для повышения устойчивости диалога необходимы новые политические стимулы, решительное руководство и более широкая поддержка. Такая поддержка могла бы исходить от парламентариев, аналитических центров, СМИ и организаций гражданского общества. Развитию «структурированного диалога» также способствовало бы более четкое определение того, как должна развиваться дискуссия и какие темы она должна охватывать.

\section{Укрепление сотрудничества в рамках программной деятельности}

Одной из целей программы «Соответствие поставленным задачам» было укрепление сотрудничества в рамках программной деятельности ОБСЕ, в частности, путем привлечения новых доноров и партнеров. Интерес к партнерству с ОБСЕ и финансированию ее деятельности растет в частном секторе. Ее программную деятельность все чаще готовы поддерживать другие нетрадиционные доноры, такие как международные организации и финансовые учреждения. Чтобы не упустить эти возможности, ОБСЕ следует адаптировать свои правила и порядок работы. Первые усилия в этом направлении были предприняты в рамках пересмотра управленческих процессов в секретариате, в частности, путем разработки стратегии мобилизации ресурсов.

Наряду с соответствующими подразделениями секретариата важную роль в осуществлении программной деятельности ОБСЕ играют ее полевые присутствия и институты. Положительной тенденцией последних лет стало значительное уменьшение политического давления на них со стороны принимающих стран. Это во многом объясняется тем, что нам удалось наладить сотрудничество между ОБСЕ и принимающими странами на условиях партнерства и укрепить заинтересованность властей в успешном функционировании полевых присутствий. На сегодняшний день широко распространено мнение о том, что присутствие ОБСЕ в стране выгодно, поскольку оно способствует проведению важных реформ на национальном уровне. Помимо заинтересованности местных властей важными факторами обеспечения эффективности и действенности ОБСЕ на местах являются четкий статус и координация с другими международными акторами. 
Полевые присутствия ОБСЕ действуют на основе всеобъемлющего подхода к безопасности и должны осуществлять деятельность во всех трех его измерениях. Еще одним сравнительным преимуществом полевых присутствий ОБСЕ является их близость к правительству принимающей страны и восприимчивость к его пожеланиям. Однако оба эти обстоятельства чреваты риском распыления ресурсов полевых присутствий ОБСЕ. Важно, чтобы руководители миссий в тесном контакте с принимающими государствами разрабатывали четкий долгосрочный план деятельности. Рассчитанная на несколько лет стратегия поможет определить, в каких сферах следует сконцентрировать экспертные знания и основную часть ресурсов. Это не приведет к менее чуткому реагированию на потребности принимающего государства, но позволит более четко очертить сферу деятельности ОБСЕ в стране и сделает более понятной ее практическую значимость. Переход от «проектного» к «программному» подходу может показаться простым, но для этого требуется полное изменение сложившейся корпоративной культуры и секретариата, и полевых присутствий, и доноров. В этой связи в ходе ревизии управленческих процессов в секретариате соответствующим образом был пересмотрен целый ряд процессов. Мы также инициировали диалог с двенадцатью основными донорами с целью формирования устойчивой культуры программной деятельности.

Еще одна сложная задача - оказание программной поддержки тем заинтересованным в сотрудничестве государствам-участникам, в которых нет официальных присутствий ОБСЕ. К таким государствам относятся, несомненно, Беларусь, Армения и Азербайджан. Что касается первых двух государств, то там уже были предприняты попытки объединить отдельные проекты в рамках страновой программы. Однако опыт последнего времени свидетельствует о трудностях, требующих решения на основе общих принципов. Сотрудничество, основанное исключительно на внебюджетном финансировании, нестабильно. Рано или поздно на такие программы придется выделять средства из регулярного бюджета. Даже если в стране нет официального присутствия ОБСЕ, необходимы правила, определяющие отношения с принимающим государством. В отсутствие таких правил ОБСЕ не может открыть счет в местном банке или обеспечить защиту своих сотрудников. Если ОБСЕ желает разработать согласованную страновую программу и поддерживать политический диалог с властями принимающей страны, необходимо координировать действия исполнительных структур организации.

Как отмечается в программе «Соответствие поставленным задачам», сложные проблемы в сфере безопасности требуют междисциплинарных решений. Для этого необходимо взаимодействие различных структур ОБСЕ, на основе которого могут быть привлечены различные экспертные ресурсы и может быть достигнут общий результат. Примером такого подхода может служить проект по наблюдению за судебными процессами, который будет реализовываться на Западных Балканах при поддержке ЕС начиная с 2021 года. ОБСЕ будет обладать сравнительным преимуществом в качестве партнера ЕС, если она сможет сочетать понимание гео- 
графического контекста и близость ее полевых присутствий к местным властям с экспертными знаниями Бюро по демократическим институтам и правам человека в области наблюдения за судебными процессами. Для этого необходима координация со стороны секретариата. Деятельность исполнительных структур ОБСЕ будет более успешной, если они будут взаимодействовать друг с другом в соответствии с провозглашенным ООН принципом «единства действий». Однако государстваучастники не всегда поддерживают такой подход. Критика «автономности институтов» повторяется ими как мантра, а вот призывы к сотрудничеству и координации деятельности исполнительных структур звучат редко. Однако границы автономии становятся очевидными, когда речь заходит об утверждении бюджета или назначении руководителей исполнительных структур.

\section{Выводы и рекомендации}

Итоги реализации программы «Соответствие поставленным задачам» являются неоднозначными. Тем не менее были приняты важные меры, направленные на повышение эффективности исполнительных структур ОБСЕ. Это свидетельствует о том, что реформирование организации возможно. Ниже представлены рекомендации о том, как государства-участники и исполнительные структуры могут далее способствовать этому процессу.

- Государствам-участникам следует предоставить бо́льшую свободу действий и оказывать большую поддержку секретариату и другим исполнительным структурам в деле совершенствования управленческих процессов и организационных структур, а также воздерживаться от вмешательства в мельчайшие детали их деятельности.

- Государствам-участникам следует реформировать и упростить бюджетный процесс, в идеале - путем утверждения бюджета на два года и введения долгосрочного планирования программной деятельности и капиталовложений.

- Председательству ОБСЕ следует согласовать на политическом уровне с государствами-участниками, являющимися основными плательщиками в бюджет, необходимость пересмотра шкал взносов.

- Следует внедрить механизм ${ }^{6}$, обязывающий государства-участников принимать сводный бюджет до конца календарного года.

- Государствам-участникам следует отказаться от принципа нулевого номинального увеличения бюджета и либо обеспечить ОБСЕ достаточными ресурсами для выполнения возложенных на нее задач, либо составить более четкий и короткий список приоритетов в рамках более долгосрочной стратегии. ОБСЕ не может продолжать делать больше, тратя меньше. 
- Следует и дальше укреплять потенциал секретариата в области стратегического планирования, совершенствовать инструменты стратегического планирования, такие как долгосрочное планирование программной деятельности и работы расширенной «тройки».

- Государствам-участникам следует расширять и в полной мере использовать неофициальные форумы для ведения полноценного диалога. Необходимо усилить «структурированный диалог» путем повышения его общественной значимости, увеличения срока председательства в неофициальной рабочей группе и плана работы до двух лет, повысить его устойчивость, заручившись поддержкой со стороны научно-исследовательских организаций, аналитических центров и организаций гражданского общества.

- Следует сфокусировать и определить стратегические перспективы программной деятельности полевых присутствий. Следует отказаться от реализации бесчисленных небольших проектов в пользу координации тщательно отобранных программ.

- Государствам-участникам следует согласовать общий порядок осуществления программной деятельности в странах, в которых нет официальных присутствий ОБСЕ. Финансирование страновых программ может осуществляться как за счет средств сводного бюджета, так и за счет внебюджетных ресурсов, а их реализация на месте может поручаться техническому персоналу в соответствии с правилами, согласованными с принимающими государствами.

- В целях расширения сотрудничества с нетрадиционными партнерами, такими как крупные региональные организации, международные финансовые институты, агентства по оказанию помощи и субъекты частного сектора, в том числе частные фонды, следует изменить существующие правила и образ мышления.

Поддерживая «Призыв ОБСЕ к действию», в котором более пятидесяти бывших руководителей организации выступили за то, чтобы активизировать «участие на политическом уровне в усилиях по сохранению способности ОБСЕ и далее работать над эффективным преодолением этих вызовов» [в области безопасности] ${ }^{7}$, мы рекомендуем Совету министров согласовать «договор о надежно функционирующей организации». Благодаря этому такие цели, как своевременное обеспечение ОБСЕ достаточным бюджетом, преодоление преград, препятствующих принятию повестки дня плановых заседаний, и содействие проведению реформ, были бы включены в число политических приоритетов. Такой договор стал бы свидетельством политической приверженности тому, чтобы ОБСЕ по-прежнему (или вновь) соответствовала стоящим перед ней задачам. 


\section{Примечания}

1 В статье автор высказывает личную точку зрения. Она не отражает официальную позицию Швейцарии или Федерального департамента иностранных дел Швейцарии. Данная публикация не является публикацией Федерального Департамента.

2 На встрече Генерального секретаря с руководителями делегаций 14 февраля 2018 года государствам-участникам был представлен неофициальный документ с изложением десяти пунктов программы реформ.

3 Программа реформ охватывала десять тематических областей. В статье подробно рассматриваются лишь некоторые из них. Результаты всесторонней оценки, над которой автор работает в настоящее время, будут опубликованы в 2021 году.

4 Первоначально мандат Генерального секретаря был определен на встрече Совета министров в Стокгольме в 1992 г. Наиболее важные дополнения в него были внесены решениями Совета министров, принятыми на встречах в Порту в 2002 г., Софии в 2004, Брюсселе в 2006 и Вильнюсе в 2011 г. См.: Третья встреча Совета. Резюме выводов. Приложение $1 / /$ Официальный сайт ОБСЕ. URL: https://www.osce.org/files/f/documents/e/8/40346.p df; Десятая встреча Совета министров, 6-7 декабря 2002 года. - С. 51 // Официальный сайт ОБСЕ. URL: https://www.osce.org/files/f/documents/5/8/40526.pdf; Двенадцатая встреча Совета министров, 6-7 декабря 2004 года. - С. 60-61 // Официальный сайт ОБСЕ. URL: https://www.osce.org/files/f/documents/7/7/41817.pdf; Четырнадцатая встреча Совета министров, 4-5 декабря 2006 года. - С. 59-60 // Официальный сайт ОБСЕ. URL: https://ww w.osce.org/files/f/documents/4/2/25070.pdf; Восемнадцатая встреча Совета министров, 6-7 декабря 2011 года. - C. 14-17 // Официальный сайт ОБCE. URL: https://www.osce.org/files/f /documents/f/f/88843.pdf.

5 В пункте 3 документа MC.DOC/4/16 задачи «структурированного диалога» изложены следующим образом: «Сегодня в Гамбурге мы принимаем на себя обязательство изучить, среди прочего, вопрос о том, каким образом можно обратить вспять негативные явления в области контроля над обычными вооружениями и архитектуры МДБ в Европе. Вместе мы будем работать над созданием условий, позволяющих вдохнуть новую жизнь в контроль над обычными вооружениями и МДБ в Европе. Твердая приверженность государств--участников ОБСЕ полному выполнению и дальнейшему развитию договоренностей о контроле над вооружениями имеет существенно важное значение для укрепления военно-политической стабильности в регионе ОБСЕ». См.: От Лиссабона до Гамбурга: Декларация о 20-й годовщине принятия Концептуальной базы ОБСЕ для контроля над вооружениями // Официальный сайт ОБСЕ. URL: https://www.osce.org/files/f/documents/8/1 /290656.pdf.

6 Оригинальные идеи предложил, например, министр иностранных дел Румынии Теодор Мелешкану на неофициальной встрече Совета министров в Высоких Татрах. Он предложил представлять сводный бюджет на рассмотрение Совета министров в начале декабря. В поисках альтернативных вариантов можно обратиться к передовому опыту других международных организаций.

7 Призыв ОБСЕ к действию: подтверждение общей цели. Парламентская Ассамблея ОБСЕ, 4 декабря 2020 г. URL: https://online.flippingbook.com/view/779749/. 